\title{
'A place of great trust to be supplied by men of skill and integrity': assayers and knowledge cultures in late sixteenth-and seventeenth-century London
}

\author{
Jasmine Kilburn-Toppin \\ Postdoctoral Researcher, The School of History, Rutherford College, University of Kent, \\ Canterbury, CT2 7NX.
}

J.Kilburn-Toppin-551@kent.ac.uk

The wardens of the early seventeenth-century Goldsmiths' Company stressed that the role of company assayer was truly 'a place of great trust to be supplied by men of skill and integrity'. ${ }^{1}$ Expertise and honesty were ideal characteristics for artisans entrusted with great responsibility. Master assayers at Goldsmiths' Hall on Foster Lane, in the heart of the city, and at the Royal Mint, in the Tower, made trials to determine the precious metal content of bullion, plate, and coinage. It was only through 'the light of the assay' that contemporaries might know 'what virtues or evilness' were contained within metals. ${ }^{2}$ The results of their metallurgical experiments directly impacted upon the reputations and livelihoods of London's goldsmiths and merchants, the credit of their institutions, and the fineness of coin and bullion. It was widely acknowledged in urban society both that assayers were a highly skilled artisanal grouping, and that their knowledge and expertise, like the materials with which they worked, were extremely precious. More broadly, across sixteenth-and early seventeenth-century Europe, against the backdrop of crises in specie, and the mining boom, assay practitioners garnered new respect and prestige. ${ }^{3}$

The knowledge and working practices of master assayers were also deemed to be valuable by those in London society with a broader interest in material trials, or experiments. Engaged in the separation and transformation of matter, assayers and the affairs of their workshops were a curiosity for those interested in the secrets of nature. As Lazarus Ercker, a sixteenth-century assay practitioner and mint official wrote, 'this Art of Assaying is the very Inlet and Mother of many other honourable and profitable Sciences as Experience teaches us, and the more a man finds out, the more he is stir'd up to the contemplating and doing of things of an higher Nature.' ${ }^{4}$ A merchant reported in 1622 that 'coming to the Assay-house [within the Tower liberties], there we found diuers gentlemen desirous to see the manner of making of Assayes of Gold and Siluer'. ${ }^{5}$ John Evelyn, diarist, writer, and founder member of the Royal Society, recorded in July 1678 'I went to the Tower to try a Mettal at the Say-Masters, which [disappointingly] onely proved Sulphur'. ${ }^{6}$ Surviving notebooks and recipes compiled by amateur gentlemen natural philosophers, such as Hugh Plat, and Clement Draper, are also replete with techniques pertaining to the assayer's testing and separation of metals by fire, solution, and touchstone. ${ }^{7}$ In his 1682 translation of Ercker's influential German text on metallurgy, Sir John Pettus FRS presented assaying as one of those bodies of knowledge that would make the 'Arts and Sciences flourish'. Pettus thus claimed to be contributing to 'the free communication of such things as had many Ages before lain secret'. ${ }^{8}$ 
As an occupational group, or knowledge community, assayers cannot be neatly categorised into craft, commercial, or 'scientific' realms. Their activities and exchanges belie any purported boundaries between artisanal, mercantile, and experimental worlds. Moreover, despite the best efforts of institutional authorities, their craft secrets could not be contained within the walls of workshops at Goldsmiths' Hall, and the Mint. The embodied expertise of assayers at work was observed and commented upon by interested parties, and occasionally taught to gentlemen by insubordinate artisans. Manuscripts alleging to reveal the mysteries of the assayers' working practices circulated within the metropolis. Notwithstanding the significance of their professional activities to contemporaries, assayers and their knowledge cultures have barely featured in cultural, commercial, or scientific histories of early modern London. Individual assayers are fleetingly mentioned in institutional histories, but they never take centre stage; and we have no clear sense of collective practices, epistemologies, or social networks. ${ }^{9}$

This absence of London's assayers from wider discussions of knowledge communities and cultures is all the more striking in view of the flourishing academic interest in artisanal, scholarly and mercantile exchanges. Across urbanised Europe, long-standing boundaries between workshop experimentation and intellectual/humanistic discourse were breaking down. ${ }^{10}$ In north Italy and south Germany the textual and pictorial elaboration of the mechanical arts in codices allowed their transformation from "know-how," available for constructing things in the world, to "knowledge" involving rational or mathematical principles' ${ }^{11}$ Craftsmen in the free imperial cities of the Holy Roman Empire developed an 'artisanal epistemology', articulated through material products of the workshop and written treatises on the mechanical arts. Pamela Smith has argued that this distinctive philosophy was centred on the craftsman's experiential understanding of the natural world, 'a way of knowing nature' gradually accumulated through years of physical toil in the workshop. Knowledge was achieved by doing. Crucially, in addition to enhancing the prestige of (certain) craft practitioners, Smith interprets this artisanal epistemology as a central force behind the development of natural philosophy and the experimental method. ${ }^{12}$ The work of Deborah Harkness has drawn attention to 'the densely social communities of practice' which formed the bedrock of London's seventeenth-century empirical culture. Medical practitioners, mathematical instrument makers, botanists, and alchemists, among other groups, developed communities, literacies, and practices 'that led to an increasingly sophisticated hands-on exploration of the natural world'. ${ }^{13}$

This article is intended as a contribution to this broader interrogation of making, testing, knowing and experimenting in early modern Britain and Europe. It sets out to address a series of broad questions about the nature of assayers' working practices and epistemologies. What were the characteristics of an expert assayer? How was their expertise acquired, and why might this be codified? How significant were London's institutional bodies, specifically the Goldsmiths' Company and the Royal Mint, in developing collective identities and attitudes to 
knowledge making? To what extent can we speak of a distinctive knowledge culture of assay trials? And, finally, how might we conceptualise the assayers' contribution to, or interaction with, London's broader 'scientific culture'? These issues are explored through a wide-ranging body of sources, including institutional court minutes and accounts, artisanal petitions, mercantile guidebooks, diaries, correspondence, recipe books, and natural philosophical treatises. As far as the sources allow, the discussion is centred upon the perspective of the master assayers themselves.

This examination of the culture of assay in London begins with the institutional workshop spaces in which assayers undertook their professional activities, and the corporate cultures of which they were a part. We then turn to the manuscript cultures through which assayers codified and communicated knowledge, secrets and techniques to broader urban audiences, perhaps beyond the walls of craft and commercial establishments. Finally, we assess exchanges, and social and epistemological tensions, between assayers and the wider community of Londoners engaged in scientific knowledge production and dissemination.

\section{Institutional spaces and knowledge cultures}

From the thirteenth century, the Royal Mint was housed at the Tower of London. The Tower mint was the primary institution in England for the production of silver and gold coin. Its officials and moneyers "were incorporated as "one body perpetual" with the right to use their own common seal, to hold land, and to sue in any court'. ${ }^{14}$ The built environment of the Mint consisted of a series of structures which gradually spread, by the end of the fifteenth century, to fill the narrow space between the inner and outer walls, or curtain walls, of the Tower. The most significant Mint buildings were situated along what was known as Mint Street, which ran northwards from Byward Tower, up to Legge's Mount. ${ }^{15}$ Archaeological excavations undertaken in the 1970s at Legge's Mount, the north-west corner of the Tower, uncovered brick buildings with furnaces, and the remains of crucibles (clay pots), bone ash cupels, parting and distillation vessels, and scrap metal; all crucial apparatus and materials for metallurgical workshop processes. This was almost certainly the location for the assaying of silver, and parting of silver and gold. ${ }^{16}$ The assay master, in residence at the assay house at the Tower mint, had the crucial responsibility of testing the quality of bullion and coinage. ${ }^{17}$ A contemporary treatise stressed that the assay master whose charge is of the greatest weight [of all Mint officials] and requireth most skill for his is a judge of the standard between the prince and the subject' ${ }^{18}$ During the Trial of the Pyx, the master assayer's integrity and expertise were regularly put to the test. This ceremonial testing process involved the assay of a sample of coins produced at the Mint by a jury of experienced goldsmiths, to ensure the coinage met the standards set by the crown. ${ }^{19}$

The other major institutional assay workshop was located in the centre of the city; from December 1478, an assay house and a salaried assayer were located in Goldsmiths' Hall. ${ }^{20}$ 
This institutional building was situated on the corner of Foster Lane and Maiden Lane, in the midst of a dense network of goldsmiths' workshops and retail spaces, just north of the westend of Cheapside. In the late fifteenth century, a centralised system of daily testing and marking (or 'touching') the wrought plate of London's goldsmiths replaced the custom by which company wardens periodically assayed plate in the premises of individual goldsmiths. ${ }^{21}$ This artisan tested the raw materials - silver and gold ingots - used by London's goldsmiths, and their wrought silver articles, to ensure that all were of the correct standard. The assay master also checked the weights used by precious metal workers. The oath of the common assayer emphasised the significance of his personal integrity:

You shall swear to [...] truly assay all such gold and silver as shall be brought to you to assay. And also you shall melt all pieces of gold and silver delivered to you truly and impartially, without any deceit, to the least waste and damage possible [...] And every article of gold and silver that you receive you shall keep safely, recording it all in writing and returning it honestly when you are asked to do so, making a true account of it uninfluenced by favour or affection, hatred or ill-will. ${ }^{22}$

A representation from the 1670 s of the interior of the assayer's workshop at Goldsmiths' Hall reduced the complex workshop processes, and social relationships, to a series of numbered illustrations (figure 1).

The lived reality of the common assayer's working practices proved to be much more complicated than this oath and visual depiction suggested, not least because the testing process was inherently subjective and volatile. For fire assay, also called cupellation assay, the practitioner took a sample of precious metal from the article to be tested, which was weighed, and then melted down multiple times in a cupel (cup of bone ash) with lead until the base metals in the sample were absorbed into the cupel. Base and precious metals thus separated, the fineness of the pure sample, or bead, was then weighed and calculated. ${ }^{23}$ Assay by fire involved an experiential understanding of many workshop variables, including furnace temperatures, and the malleability of metals. Materials and elements might behave in unexpected ways. A fourteenth-century manuscript note from the Royal Mint recommended that in every instance of testing 'at least three impeccable assays should be made, lest through overheating or otherwise the silver should have spurted out from one of the assays and lest from draughts or a failure of the fire, the assay should have cooled, or by the fall of coals or in any other way the assay or silver should have been diminished. ${ }^{\prime 24}$ The assayer at Goldsmiths' Hall and the Tower mint (sometimes, controversially, the same man) was also enmeshed in a complex series of institutional relationships, hence, acting truly and impartially in the eyes of guild and mint governors, merchants, and working goldsmiths was oftentimes a challenge. But for our purposes, fortunately, it was precisely when relations between the goldsmiths and their assayer broke down that accounts of expected standards, customs and values are most clearly articulated in the company archive. ${ }^{25}$ 
Managing the physical space of the assay house at Goldsmiths' Hall was a perennial and unique challenge for the guild. In part this was a consequence of its location within a multifunctional institutional space. The famed sixteenth-century metallurgist Georgius Agricola recommended that the assayer 'should close the doors of the room in which the assay furnace stands, lest anyone coming in at an inopportune moment might disturb his thoughts when they are intent on the work'. ${ }^{26}$ The deputy assayer in early modern London had no such splendid isolation. A survey of Goldsmiths' Hall dating from the 1680 s shows the extent to which the assayer's working and living space was embedded in the company building, and the wider urban environment (figure 2). At any one time within Goldsmiths' Hall numerous political, social, domestic and commercial spatial practices were undertaken by men (and occasionally women) of varying statuses. As we will see, unsolicited eyes observed workshop activities, and ears overheard company secrets.

The Goldsmiths' concerns about interferences with the assayer's labour were often more pointed than mere distraction. There was also a distinct corporate cultural ambiguity about the extent to which the common assayer's working practices ought to be made visible to interested parties. The deep-rooted ideal of secrecy in relation to the craft mystery (the valuable collective embodied skills and techniques of the guild), meant the assayer's workshop ought to be shielded from prying eyes and inquisitive ears from outside of the goldsmiths' guild. ${ }^{27}$ The Goldsmiths' Company's first extensive book of Ordinances and Statutes, compiled in September 1478, included appropriate penalties 'if any man reveals the secrets of his craft' ${ }^{28}$ More specifically, the trials undertaken by institutional assayers were meant to be discreet and private in order to uphold the allegedly impartial nature of the process, and they were thus ideally concealed from all but the employees of the workshop and institutional authorities. And yet, this very secrecy, and apparent lack of transparency concerning the deputy assayer's workshop activities, repeatedly led to complaints and controversies. In the hands and judgements of London's assayers lay the purity of specie and the livelihoods of artisans and merchants. The honesty and quality of their work also reflected upon institutional reputations. Thus a balance was continually renegotiated between 'secrecy' and 'openness' in relation to the working space of the Goldsmiths' Company's assay master. Unlike, for example, the company parlour, a site of civic governance that became progressively more exclusive over the course of the sixteenth and early seventeenth centuries, regulating access to, and views of, the assay house was an altogether trickier endeavour. ${ }^{29}$

The Goldsmiths' Company archive sheds light on the challenges faced in restricting observation and entry to institutional assay workshops. First, craft secrets were a marketable commodity, and thus might be communicated and performed outside of the workshop and sold. In 1560 the assistants chastised their assay worker John Kirk for bargaining with certain gentlemen of the Court 'to teach them the feate of assayes making'. The wardens told him 
that it was unlawful, and contrary to his oath, 'to open that or any other secret of his mystery to any man that is not free thereof.' Kirk said that 'he had taught others,' and 'would do it again for money,' and 'stood stoutly on his defence'. ${ }^{30}$ We find in the early seventeenth century that workmen employed by the deputy assayer were gossiping about the 'secrets of the assay house' to stranger goldsmiths on a street adjacent to Goldsmiths' Hall. ${ }^{31}$ The physical boundaries of the assayer's workshop, especially doors and windows, also had to be closely monitored when trials were taking place. In August 1601, for instance, the company governors ruled that no man should walk on the terrace while the assayer and touch wardens were at work 'and doe sitt and debate about the affaires of this societie'; from the vantage point of the elevated terrace one could covertly observe the activities taking place in the assayer's chamber. ${ }^{32}$

The space of the assay house was also understood by contemporary artisans to be intimately associated with the skill and integrity of its office-holder. In extremis the physical state of the built environment, and the (dis)honourable reputation of the assay master, were even seen to be mutually reinforcing. This perceived association is amply demonstrated by two especially contentious and long-running disputes between the assay master and the wider body of London's goldsmiths. In the 1560s common assayer Richard Rogers was in repeated conflict with the assistants of the company. ${ }^{33}$ Tensions were generated in part because he held a prominent position at the Mint, in addition to his company role. ${ }^{34}$ As the assayer at Goldsmiths' Hall was called upon to be a check on the assayer at the Tower, through the assay of the coinage at the Trial of the Pyx, Rogers was said to be in effect 'his owne judge, not without great suspicion of partiality'. ${ }^{35}$ Suspicions about Rogers were also focused upon his keeping an open shop on Cheapside 'where he also dwelleth'. Despite the ordinances of the guild, which stated that the common assayer should reside in Goldsmiths' Hall, Rogers would not 'give over his occupueyncye and dwellynge in Chepe, and come dwell in his house [...] $w[i]$ thin goldsmiths hall' ${ }^{36}$ The assistants lamented in December 1564 that the tenement which rightly belonged to the office 'now standeth and of long tyme hathe stande voyde and emptie to the great harme and decay of the same'. The governors of the guild here equated the increasingly decrepit edifice of the assayer's institutional residence with the diminishing integrity of the officeholder. Three years later, the assistants were still complaining of Rogers's 'frivolous delays' in removing himself from Cheapside to the 'house belongyng to his office of assayes makynge as other his pr[e]decessors [...] tyme out of mynde have done'. When Rogers was finally dismissed from the company post in 1567 , he pointedly kept in his possession the physical contents of the Assay Office, including the weights and tools for trials, belonging to the guild, until the matter was resolved to his satisfaction. ${ }^{37}$

The exceptionally protracted early seventeenth-century disagreement between deputy assayer John Reynolds, and a group of working goldsmiths, also speaks directly to matters of skill and integrity, and legitimate oversight of the space of the assay house. ${ }^{38}$ In May 1629, a group of thirteen working goldsmiths presented a petition thoroughly besmirching Reynolds's 
personal honour and professional integrity. Clearly their grievances had been mounting for some time. The document detailed eight reasons why 'wee the workemen [...] conceave that neither hee the said assayer nor his servants are fit to judge or refuse our plate'. The root of their objection was that, far from acting with the integrity that his office required, Reynolds, having 'sett aside all fear of God hath violated his annual oath by favour, affection, hate and evil will to diverse [...] men of this mistery'. Reynolds was said to be 'partial in his office, allowing plate of the fineness of the standard to be touched for them that he favoureth and causing the wardens to break some far better of such workemen disaffected by him'. In a revealing insight regarding the anticipated personality traits of a master assayer, Reynolds was said to lack control of his passions or senses. He had an irrepressible 'fury or rather madness' and 'in his rage hath misused many' by breaking plate that was later proved to be up to standard. The petitioners especially resented the idea that Reynolds presumed himself to have royal protection, on account of his dual role at Goldsmiths' Hall and the Tower, 'affirming himself to be his majesties servant daring any man whome he hath wronged once to touch him, commanding the wardens in the kings name to do as he would have them' ${ }^{39}$

Reynold's counter-petition to these accusations of partiality, maliciousness and mismanagement, speaks directly to the matters of skill, honesty and regulation of the space of the assay office with which this article is concerned. Reynolds assured the wardens that the oath of his office was 'a bond of Integrity laid upon his conscience his sufficiency of skill and knowledge required for that place, being not inferior to any his predecessors'. Further, the master assayer proposed that the primary cause for the workmen's discontent was the new spatial context within which the assayer's judgements were enacted. Reynolds suggested that the 'innovation' of destroying 'men's stuffe' in the assay house rather than the parlour, and 'without due ceremonie and solemynitie', was encouraging 'turbulent spirits'. ${ }^{40}$ Reynolds was dismissed from his role as common assayer at Goldsmiths' Hall, but his comments regarding the witnessing of work and judgements were acted upon. The company court decreed that all deceitfully made plate should be broken in the parlour before two wardens, not in the Assay House, or elsewhere, and that the clerk should certify the deceit, and the workman's name, to the next court. ${ }^{41}$ Moreover, select groups of working goldsmiths were encouraged to observe trial personally. ${ }^{42}$ Making the workshop activities of the company assayer visible to the wider body of goldsmiths was significant at this moment to repair the trust and accountability of the assay house.

Collective judgements were also important when London institutions were making assessments of the expertise and suitability of artisanal candidates for the post of common assayer or master. When hiring a new deputy assayer, the Goldsmiths' Company required short-listed applicants to demonstrate their practical skills in front of select groups of goldsmiths at the assay house in Goldsmiths' Hall. ${ }^{43}$ Similarly, the Mint instigated a competitive process of evaluation for their assay master. When in post as Master of the Royal Mint, Isaac Newton wrote extensively of a prolonged controversy between two candidates. 
In writing his defence of assayer Charles Brattle, and simultaneously playing down the claims and expertise of assayer Catesby Oadham, Newton disclosed considerable detail about the assessment process. Moreover, it is notable that a formal practical appraisal was deemed necessary, despite the fact that Charles Brattle succeeded his brother, Daniel Brattle, as queen's assay master, having aided him in this post for several years. ${ }^{44}$ Brattle and Oadham, and two other unnamed assayers, 'had a Comparative Trial before the officers they made each of them Eight Assays of Gold in four successive Fires, two in artiffice, and as many of silver [...] $\mathrm{M}^{\mathrm{r}}$. Brattel was [...] observed to handle things with more Dexterity and dispatch'. ${ }^{45}$ Tellingly, one of the disparaging arguments put forward about Oadham focused precisely upon the lack of perceived legitimacy of (non-institutional) witnesses. Newton wrote that few of the 'Merchants \& Goldsmiths' who certified Oadham's skill were 'men of note for skill in assaying, or ever met together to see him make a competent number of successive Assays whereby they might be able to judge of his skill'. ${ }^{46}$

Presumably assayers did learn their craft through apprenticeships to expert practitioners, but since workshop learning was based upon observation, experience, and tacit exchanges, not codified knowledge, there is a general lacuna of evidence for the learning of crafts in early modern Britain and Europe. ${ }^{47}$ It is evident, however, that the skills of assaying, and more specifically, the office of master assayer at the Royal Mint and the Goldsmiths' Company were roles that were ideally kept within trusted families (or expert networks), such as the aforementioned Brattles. ${ }^{48}$ After an extraordinary thirty-five years of service, company assayer William Dymock requested in 1611 that the Goldsmiths' Company might be 'pleased to grant the reversion of his office to his son'. He stressed that over his lengthy tenure he had 'educated and made his son fit for the office'. Upon his death six years later Dymock's request was granted, and his son, Thomas Dymock, succeeded to the office. In 1653 it was reported to the court of wardens that Abraham Jackson, the son of company assayer Alexander Jackson, was 'helpful to his father in the exercise of the place'; as a consequence of which the wardens remitted him the fee of his freedom. Two years later the company offered to pay Abraham, 'brought up to the mystery of an assayer', twenty pounds per annum. In 1661 he was officially sworn an assayer for the Goldsmiths' Company. ${ }^{49}$

\section{Knowledge communities and manuscript cultures}

In early modern cities institutional knowledge cultures were not just observed in the workshop. Urban residents might also encounter artisanal practices and customs through texts. Manuscripts and printed treatises on craft practices were produced and circulated in ever greater numbers in sixteenth- and seventeenth-century Europe, and allegedly revealed to literate audiences 'the secrets of the arts' which had formerly been hidden within artisanal work sites. ${ }^{50}$ Texts on craft secrets were part of a diverse genre of 'books of secrets', which included, but was not limited to, 'directives to make everyday foodstuffs and medicines or a set of alchemical instructions or technical trade know-how'. ${ }^{51}$ As Pamela Smith has suggested, 
"books of secrets [...] were an articulation of the experiential knowledge of craftspeople and practitioners that was "hidden" in the things of nature or in the material craft.' 52 We focus here upon two such London-based manuscripts, which emerged from an established tradition of writing about metallurgical processes and were rooted in the institutional workshops whose spatial and social practices we have just observed. These manuscripts provide unusual insights into the techniques, proficiencies, materials and tools required for undertaking trials by assay. They also demonstrate the contemporary significance of the codification of expertise.

On 20 June 1606, the wardens of the Goldsmiths' Company were presented with the gift of a manuscript whose author 'had taken greate paines in translat[i]on'. ${ }^{53}$ The work was entitled The Gouldesmythes' Storehowse. Wherein is layde up many hidden secrets of that Ingenious Misterie (figure 3). The text had been presented, 'compiled, made, and drawen into this Method by H-G. Citizen and Gouldsmythe of London', and is dated $1604 .{ }^{54}$ As is typical of books of craft secrets and technological treatises, the Storehowse explores a wide variety of subject matter, including the social and institutional organisation of the Mint, translations of late-medieval lapidaries, and alchemical experiments and formulas. ${ }^{55}$ The manuscript consists of eighty-three quarto leaves and is divided into three books, containing multiple short chapters. ${ }^{56}$ Thematically, the overall focus of the work is on the activities of assaying, refining and monetary circulation.

It is probable that this manuscript was a collaboration between a father and son, both named Hannibal Gamon, and both members of the Goldsmiths' Company. The son, Hannibal Gamon the younger (bap. 1582), graduated from Broadgates Hall, Oxford with a BA degree in 1603, and an MA in $1606 .{ }^{57} \mathrm{He}$ was a company exhibitioner, meaning that he received financial support from the Goldsmiths' Company towards his university education. In 1603 the company gave him five pounds 'toward his grace in the universitie and the charges of his com[m]encement', and on receipt of the manuscript in 1606, the guild gave him ten pounds towards his commencement 'to be Master of artes'. ${ }^{58}$ The Gouldesmythes' Storehowse thus appears to have been a learned gift presented in return for the company's patronage of Gamon's higher education; indeed the company's arms feature prominently on the title page of the manuscript, and the wardens were pleased that he 'shewed A thankfull minde to the Company in the dedicat[i]on' of the book. ${ }^{59}$ Hannibal Gamon senior gained his freedom in 1575 and was a practising goldsmith, with premises on Cheapside. Multiple members of the Gamon family were also members of the Goldsmiths' Company, including Henry Gamon, brother of Hannibal Gamon the younger (who gained his freedom through apprenticeship in 1604), and Richard Gamon, son of Hannibal Gamon the younger (who gained his freedom through patrimony in 1626). ${ }^{60}$

The Gouldesmythes' Storehowse contains many references to ancient and contemporary sources, including Aristotle's Ethics, Pliny the Elder's Naturalis Historia, and Agricola's De re 
Metallica. ${ }^{61}$ It is also evident that the authors of the Storehowse had read a copy of Thomas Aunsham's early sixteenth-century manuscript on minting and assaying. ${ }^{62}$ As deputy to comptroller Sir Henry Wyatt, Aunsham, who 'gave daily attendance' at the Royal Mint, was ideally placed to write about institutional knowledge cultures. He was also well informed about continental practices of metallurgy. ${ }^{63}$ Hannibal Gamon the younger was evidently well positioned to compile a treatise that included scholarly references, and details about contemporary craft practices and controversies. There are, though, certain particulars about workshop practices which could only have been known by his father. These details include a first-hand account of the outcome of the Trial of the Pyx in 1600 and 1601, for which Gamon senior had served on the jury. ${ }^{64}$ The likely circumstances behind the composition of the Storehowse - of a university-educated author in dialogue with workshop-based artisanal practitioners - are similar to the 'collaboration and communication' between different cultures of learning and knowledge that Pamela Long has identified in southern Germany and northern and central Italy from the early fifteenth century. ${ }^{65}$ Authors of early-modern technical treatises often originated from artisanal families. ${ }^{66}$

The second institutional manuscript under examination here is entitled Mint and Moneta (Mint and Money). This text comes from the archive of the Royal Mint, and is a presentational copy, but little else about the manuscript's author or the precise circumstances of its production is known. Archivists have dated it to the first decade of the eighteenth century. ${ }^{67}$ A discussion of the expertise and precision involved in metallurgical testing would have been very timely in the decade following the Great Recoinage (1696). ${ }^{68}$ The manuscript is divided into two books, consisting of numerous short chapters. The first focuses upon weights and the production and testing of coin and is, essentially, a copy of an anonymous sixteenthcentury treatise. The second is in effect a short history of the Royal Mint. ${ }^{69}$ The complexity of descriptions of workshop processes are suggestive of an author who was either undertaking these practices himself or, at the very least, was a close observer. It is evident that the author of Mint and Moneta had also read a copy of The Gouldesmythes' Storehowse, as several passages are copied verbatim. Like the writers of the Storehowse, the author of Mint and Moneta was deeply immersed in the rich literatures of metallurgy; he stressed that the contents of his manuscript were 'proved by all the most skillfullest men in these arts as well beyond the seas as here in England'. ${ }^{70}$

For the purposes of this exploration of cultures of assay, these manuscripts bring to light significant themes relating to testing, making and knowing materials, instruments and the natural world, three of which are examined here. First, the texts emphasised the importance of both experiential and propositional knowledge. The expertise of assayers in undertaking trials is said to be rooted not simply in a mathematical understanding of metallic compositions, or a book-based humanist education, but also, crucially, through experience gained through years of repetitive toil in the workshop and acutely trained sensory faculties. There is no clear distinction made here between the activities of the 'mind' and those of the 
'hand'. Second, the practitioner-authors argued that testing was a collective social process, which ideally took place in particular institutional locales, amongst select groups of institutionally-trained master craftsmen/officials. It is well established that the experimental activities of gentlemen natural philosophers had definite spatial and social dimensions; so too did artisanal knowledge making. ${ }^{71}$ Third, these sources reveal something about the interrelationship between authorship, the codification of embodied epistemologies, and institutional knowledge cultures.

In a chapter on the philosophy of money, in the first book of the Storehowse, Gamon claims that whereas every man knows by sight the basic distinction between bullion and money, assay by a 'man experte and skilful throwe practize in the Arte of Assaye Makinge', is required for 'the perfit knowledge of Golde and Sylver'. It was said by Gamon that assay by fire, through which the material purity of a metallic sample is tested, 'Requyrethe a p[er]fit Assaye man, whose $\mathrm{p}$ [er]fection must be grounded upon Artificiall Exercise; for these things doe rather consist in doinge, then in Resoninge, for they are not eselie reduced to matter of Argument, unlesse Exercise be joyned w[i]th speche' ${ }^{72}$ It was thus not enough for a man to have read about the craft process of assaying, textual learning was no substitute for first-hand manual practice, or 'Exercise'.

Through this emphasis on the embodied elements of artisanal expertise, Gamon reiterated the counsel of contemporary authorities on assaying. In Pirotechnia, one of the most influential metallurgical treatises of the early modern era, Italian Vannoccio Biringuccio stressed the importance of 'sending out for information, making observations myself, and [...] talking with someone who I knew to be experienced' ${ }^{73}$ The German metallurgist and mining and assaying practitioner Lazarus Ercker (ca. 1530-94) stated in his Treatise on ores and assaying (1580), which was inspired by Agricola's De re metallica, that 'these things cannot be pictured on paper in such a way that they can be understood and judged merely by reading about them. Reading shows you the way, but the work of your own hands gives you the experience. ${ }^{74}$

The personal qualities of the 'perfect' assayer, who must be acutely aware of any defect which would make the assay 'uncertaine and not reportable', are further developed within the Storehowse. Assaying, it was said, 'askethe a good Judgement, gotten rather by yeares and experience, then by speculation and dispute', furthermore 'besydes his grownded experience in this scyence or mysterye [the artisan] should have a perfit eie to vewe [or 'discerne'], and as stedye a hande to waye for other mens senses cannot serve him' ${ }^{75}$ The master assayer ideally had both innate and well-developed sensory perceptions that were honed through constant repetition of material experiments in the workshop. ${ }^{76}$ In order to make informed assessments of material properties and transformations he was expected to employ his full range of senses, not simply sight. ${ }^{77}$ Agricola advised practitioners to pay attention to the odour emitted when assaying gold. ${ }^{78}$ In a discussion of the evaluation of tin, Biringuccio spoke 
of 'the whitest and hardest, or, when it is bent or some thin end of it is held tightly by the teeth, is heard to crackle as frozen water does' ${ }^{79}$ In the third book on recipes for the assaying of gold and silver, Gamon wrote of the importance of hearing when testing precious metals with acid: 'to have surer knowledge therof laye your eare unto the saide glasse and yf it be full laden and charged w[i]th sylver it will sounde in this wise. bott, bott, bott' ${ }^{80}$ The author of Mint and Moneta repeated this advice about the necessity of listening when attending to and evaluating volatile workshop materials, and using taste to ascertain subtle differences of purity when conducting assay by touchstone. ${ }^{81}$

According to these author-practitioners, the metallurgical expert should thus combine extensive workshop experience and uniquely attuned sensory perceptions. The fundamental instrument in the assayer's endeavours was his own body, but this artisan also had thorough knowledge and understanding of his workshop tools; Gamon asserted that 'w[i]thowte knowledge therin, the worke master shall goe blindlye to worke' ${ }^{82}$ These artisans did not perceive any kind of tension between the application of wide-ranging haptic knowledge, including taste, smell, and touch, and the use of finely-tuned precision instruments, such as balances, that could measure with extreme accuracy. Sixteenth-century metallurgical authorities had stressed that an ability to make one's own tools, including balance, crucible, and furnace, was an essential element of an assayer's mastery. Biringuccio claimed 'that it can be said that there are almost as many different shapes of furnaces as masters' ${ }^{83}$ Ercker suggested that the filing and joining of the proof balance or scales was the most impressive achievement: it 'is a special Science, and is the true Master-piece'. Manufacture and maintenance of this precision instrument 'doth try many times a Master [...] and it certainly must be managed by an ingenious, and not a dull Soul'. The assayer had to ensure that the balances were kept clean of dust, that the scales were not agitated by currents of air, and to set the measuring instrument with 'bright and clear Glass, that the Light may come into it, and that all things may be seen' ${ }^{84}$ Attention to these variables was essential to the act of weighing, a vital part of the assayer's working practices. Accurate weighing - and written accounts - of bullion, plate, and coin were vital for keeping track of any losses or gains (or indeed thefts) as precious metals underwent transformation during assay. ${ }^{85}$ For the assayer at the Mint managing the fluidity of gold and silver, 'it is necessary to remain with the eyes always open and to keep the balance and pen always in hand' ${ }^{86}$

The authors of the Storehowse and Mint and Moneta described in detail the materials and techniques required for making cupels. Ideally these vessels were made from the burnt, crushed and compacted 'Cheek Bones of the fish called Pike, or else the sharp picked ends of Harts Hornes and for a need the Bones of Chickens' ${ }^{87}$ They also included drawings of the metallurgist's workshop instruments and equipment. The earlier manuscript includes illustrations of touch needles; the Mint text contains a rich variety of drawings of workshop instruments, including furnaces, a set of balances, crucibles, tongs, and vessels for storing solutions (figures 4 and 5). Each diagram has an accompanying textual description, and a two- 
page spread of drawings is headed 'the patterne or modell of the forme of severall adjuncts fit for to be known of a skilful assay ma[ister]' ${ }^{88}$ The assayer's balances are given special visual prominence, displayed in an ornate open-sided case. In sixteenth-century assaying texts authors explicitly stated their rationale for including illustrations. Agricola hired illustrators to represent tools 'lest descriptions which are conveyed by words should either not be understood by men of our own times, or should cause difficulty to posterity'. ${ }^{89}$ Technical drawings might thus aid the reader's understanding of artisanal processes. Whether he was a fellow practitioner or non-expert they were a help in codifying and communicating experiential knowledge. These illustrations were also undoubtedly a means of deepening interest and intrigue in the practices being described, and they capture the (early modern, and modern) reader's attention. The drawings in the Mint manuscript, in the same hand as the text, might further have been an attempt at demonstrating the expertise of the author.

Experience, repeated trials, extraordinary sensory perceptions and comprehensive understanding of workshop tools were thus all deemed to be significant features of the master assayer's practice. This is a combination of expertise for the production of knowledge with which supporters of the 'new method of philosophizing' would have been wholly in sympathy; it is (only) the assayer's social status which makes him an unreliable participant. ${ }^{90}$ The authors of these presentational manuscripts on assaying also stressed the importance of collective participation, and witnessing, of workshop activities. The labours of the assayer were ideally observed and endorsed by groups of skilled office-holders. Patrick Wallis's work on guild searches of artisanal shops and work spaces throughout the early modern metropolis similarly stresses the importance of this collective decision-making dimension. Groups of three of four citizens would apply their full range of senses and technical abilities when making judgements about material quality. ${ }^{91}$

Collective judgement was of especial urgency when the value of the coinage was at stake. The description in The Gouldesmythes' Storehowse of the Trial of the Pyx undertaken 'in one parte of ye Inner Chamber in ye Starre Chamber', affirms the social and political weight of the collective nature of artisanal knowledge making. ${ }^{92}$ The text reveals that fifteen 'Ancient and skilfullest goldsmythes' were chosen for the jury, and 'thyther they all resorte, [to the star chamber] w[i]th their glasse, waightes, stronge water, and all other things necessarye pertinent to asaye makinge'. It is indicative of the social structure of London society, and the perceived need to ritually perform social difference, that 'the Lordes goe to dynner in the nexte Roomthe, and so the Jurie goe to worke, that they maye be redie $w[i]$ th their verdict against the nobell men have dyned'.$^{93}$ In 1601, however, a year in which Haniball Gamon senior was serving on the jury, 'This Tryall being thus made, and findinge the furnace for want of use not agreable [...] we departed, to make farther Tryall at the Goldesmythes Hale' ${ }^{94}$ Similarly, the account of assay of bullion and coins in Mint and Moneta places a strong emphasis upon the collective nature of the testing process. Assay took place in a locked chamber in the sight of 'at least three' institutional officials. ${ }^{95}$ Contemporaneously Isaac 
Newton wrote of how 'it's easy for an Assayor to give a Turn to the assay of a quarter of a Grain, or an half penny weight or above for or against the Master. And if any such thing be suspected, the Assayer must Repeat his Assay, till the officers of the Mint are satisfied of his acting with skill and Candour. ${ }^{96}$

By their very nature, these accounts of assay are unusual. Craftsmen did not routinely articulate their understanding of materials, or the working of their instruments, through manuscript or print. This is in part related to the custom of secrecy concerning the collective mystery of the urban craft guild. Moreover, workshop activities cannot easily be reduced to words or pictures. The complexity and experiential nature of the assayer's work - one could not merely read about how to react to the temperature of the fire, or the smell of molten metal - means that the Storehowse did not genuinely equip the reader with sufficient knowledge to carry out the workshop practices it describes. It was not a true 'instruction' manual. ${ }^{97}$ But it is nevertheless the case that through repeated details of trials these manuscripts do reveal some significant technical details about the assayer's mystery. So why codify this precious knowledge? More particularly, why collate this knowledge in a presentational manuscript addressed to the very institution charged with safeguarding craft secrets? The authors of these manuscripts on assaying do not explain the precise purposes of their writings, but we can nevertheless infer much about the social circumstances of authorship from the texts themselves, and other metallurgical writings.

Authorship was a strategy for enhancing the craftsman's social and intellectual prestige, particularly within a cultural landscape in which manual work was generally disparaged. The demonstration of expertise in text and sketches, and repeated inter-textual references, elevated the artisan-author's status above the general mass of urban mechanicians. ${ }^{98}$ Lazarus Ercker for instance, advanced his career and patronage prospects through authorship. ${ }^{99}$ The intended effect of codifying the assayer's knowledge and working practices was surely also to further reinforce the epistemological claim of metallurgy, in general, as a legitimate field of knowledge, that could be theorised and categorised. ${ }^{100}$ In this respect it is telling that Aunsham, Gamon, and the author of Mint and Moneta, repeatedly refer to practitioners of the assayer's craft as experts 'in this scyence or mysterye', or 'masters of this science'. ${ }^{101}$ The craft mystery is presented as being synonymous with science, and these author-practitioners are asserting their expertise over this complex body of knowledge. Pamela Long has written of sixteenth-century European metallurgical texts which transformed mining from a relatively low-status occupation into a learned subject with ancient precedents, a contribution to humanist learning' ${ }^{102}$ Perhaps the authors of the manuscripts under scrutiny here had similar ambitions for the science of assay.

Finally, these technical manuscripts had an instructive function for readers. Gamon claims that ultimate skill and knowledge 'cannot in manye yeares be attayned unto only by Tradition [guild-controlled apprenticeship]; Unles[s] le[a]rninge; which is gotten by Readinge severall 
Authors, be joyned therto'. ${ }^{103}$ Apprenticeship is allegedly insufficient if a man aspires to 'completeness', or to be 'synguler in the arte'. ${ }^{104}$ Ercker hoped that his writings on assay would act 'as a furtherance to Experience, and for the use of common Mine-Workers, and yo[u]ng Assayers'. ${ }^{105}$ The experiential features of workshop training were thus ideally combined with theoretical book-learning. The texts might have been deliberately left in manuscript form to preserve the notion that their authors were revealing 'secrets' to a select group of trustworthy institutional intimates. Customarily the 'property in a [gifted] book was as much collective as private', and here the author(s) of these manuscripts present collective secrets, techniques, and traditions to the very institution that embodied the craft mystery. ${ }^{106}$

Against a backdrop of the gradual eroding of collective knowledge among goldsmiths, assay manuscripts might have had a genuine didactic function. It is a challenge to disentangle the expertise and knowledge cultures of working goldsmiths in general from the techniques of assayers specifically. 'In discussing the art of the goldsmith, it is apparent that it is an art requiring skill' - so wrote Vannoccio Biringuccio in his Pirotechnia. Such were the varied demands and expertise required of a master goldsmith, it was said 'he must outdistance all other craftsmen in learning and achievement to the same degree that their materials outdistance other metals in nobility'. Alongside design skills, dexterity, an ability to mould, and to 'have a good judgement in gems', a goldsmith 'should also be experienced not only in the technique of melting but also in the methods of assaying, parting, refining, cementing, and the like, and still many others' ${ }^{107}$ This was certainly a demanding variety of techniques and practices; even Biringuccio admitted that 'those are rare' who had truly mastered the full range. ${ }^{108}$ The authors of The Gouldesmythes' Storehowse lamented that 'wheras his skill oughte to doe anything pertinent to a golde worker, it is devided into severall mens skils'. This concern about the perceived fragmentation of the collective guild mystery was echoed by the wardens of the Goldsmiths' Company in a declaration 'read openly in the hall to all the company' in November 1607, concerning 'the arte and misterie of Goldsmithrie [...] dispersed into many partes'. ${ }^{109}$

From the late sixteenth century, the governors of London's Goldsmiths' Company were particularly concerned that the knowledge and expertise of assay specifically were becoming all too diffuse among the general population of goldsmiths. In 1570, a liveryman, John Gardener, was granted an increase in company charity, on the condition that 'he forthwith set up the practice of assays making for the instruction of the Company'. ${ }^{110}$ Half a century later, company assayer Alexander Jackson was called upon by the wardens and assistants, 'by his best endeavours [to] teach and instruct suche other of the saide companie or their children or servants as shalbe desirous of the skill and knowledge of making assaies of gold and silver'. ${ }^{111}$ In early modern London a manuscript on the literatures and practices of assay might have had a dual educative purpose for goldsmith readers, worthwhile both for youthful assayers in the process of learning the craft, and for mercantile members of the guild. Retailers and goldsmith-bankers became wealthier across the seventeenth century, both in 
real and relative terms, and gradually dominated offices within the Goldsmiths' Company. ${ }^{112}$ A text on assay would be useful for men largely detached from the production side of their trade but interested in being able to speak knowledgably and authoritatively about workshop matters. In The Gouldesmythes' Storehowse, Gamon spoke in enthusiastic tones about 'the Marchant goldesmythe, otherwise termed the Buyer and Seller'. It was said that these retailers 'must have skill and knowledge, in all these aforesaide severall knowledges. Or els[e] he cannot be este[e]med in this function a perfitt Artiste'. ${ }^{113}$

Similarly, within the institutional context of the Royal Mint, presentation manuscripts must have had an edifying purpose for prominent office holders who were detached from the artisanal practices of assaying, blanching and shearing coins. ${ }^{114}$ This lack of technical experience on the part of senior office holders at the Tower mint was common by the turn of the seventeenth century, and became an entrenched feature of institutional life. ${ }^{115}$ There was clearly a tradition at the Royal Mint for such textual offerings too. Thomas Aunsham directly addressed his early sixteenth-century treatise on minting and assaying 'to those which wilbe a $\mathrm{mr}$ or wardene or any other minesterie within the kinge Mintes'. ${ }^{116}$ We might see the early eighteenth-century Mint and Moneta in a similar vein. Like Biringuccio's 'advice on how to operate a Mint honestly and with profit', this London-based manuscript might have been directed at those who 'should need to practice it or even to talk about it and if you should find yourself in this activity it may not be new to you' ${ }^{117}$

\section{Assay and experimental philosophy: metropolitan knowledge cultures}

On 19th May 1663 Samuel Pepys visited the Assay Office at the Mint, 'and there saw the manner of essaying of gold and Silver, and how silver melted down with gold doth part again being put into aqua fartis [sic]'. ${ }^{118}$ Pepys was soon to become FRS, and later President of the Royal Society. ${ }^{119}$ He was mightily impressed by what he saw in the assayer's workshop, describing the artisan's separation of gold and silver as 'a miracle'. Pepys also went away from the Assay Office much more comprehensively educated about the theory and practices of metallurgy; 'and here I was made thoroughly to understand the business of the finenesse and coursenesse of metals, and have put down my lessons with my other observations therein'. Tellingly, in a lengthy description of the assay of silver, he described the workshop process as an 'experiment'. ${ }^{120}$

Aside from institutional office-holders at the Tower mint and Goldsmiths' Hall, merchants, and fellow craftsmen, the master assayer's workshop practices also aroused the curiosity of practitioners of the 'new science'. Presentational treatises on assay demonstrated that knowledge of the separation and transformation of metals might be codified. As we have already noted, the theorisation of craft processes was a significant feature of the interaction between artisanal and scholarly cultures. ${ }^{121}$ Attentive observation of workshop practices was also an important feature of the new experimental methodology. Salomon's House, Francis 
Bacon's utopian research institution, included numerous laboratories, furnaces, and workshops in which experiments might be conducted and nature observed. ${ }^{122}$ Actually this was not such a futuristic imagining, but 'a dressed-up representation of the real world of science in Elizabethan [and Stuart] London'. ${ }^{123}$ London's artisanal workshops were sites in which the manipulation of matter, natural materials, and instruments might be observed at close quarters. ${ }^{124}$ The history of trades programme, enthusiastically taken up by fellows of the Royal Society between 1665 and 1680, pursued this Baconian vision of increasing understanding and improving the technologies of the mechanical arts. However, it was ultimately to flounder and end in failure, in part because these gentlemen had little real prior knowledge of the challenges of communicating and codifying workshop practices. ${ }^{125}$

The experimental activities of the assayer's workshop were especially intriguing for London's gentlemen natural philosophers. It is particularly revealing that in early modern England the word 'assay' connoted both the trial of metals specifically, and 'experiment' more generally. ${ }^{126}$ As we have observed in London's institutional assay workshops and manuscripts, proficiency in assay involved a complex blend of experiential and theoretical knowledge, and ultimately an ability to transform materials. Ideally its practitioners were endowed with extraordinary sense perception. Master assayers were also experts in managing and interpreting complex precision instruments. It was moreover an established practice in London's institutional assay workshops to record every trial which took place, including detail of metallic quantities, tools, and materials; even tests that went badly wrong through human error, a faulty furnace, or unexpected material reaction were recorded. ${ }^{127}$ Experiential and instrumental knowledge, repeated trials, and the reporting and replication of experiments were of course central also to the methodology of the new experimental science. ${ }^{128}$

A fuller explanation still of the appeal and interest of assay to London's seventeenth-century natural philosophers is outlined in Pettus's 1683 text Fleta minor. The laws of art and nature in knowing, judging, assaying, fining, refining and inlarging the bodies of confin'd metals. ${ }^{129}$ Pettus had been deputy governor of the Mines Royal for thirty years at the point of publication, and FRS for two decades, and was thus seemingly well placed to present a summary of metallurgical knowledge. Composed of two parts, the first section is a translation of Ercker and the second a curious collection of 'essays on Metallick Words, as a Dictionary', penned by Pettus himself. It is tempting to see Fleta minor as a contribution to the broader history of trades project. The Royal Society certainly actively encouraged Pettus's metallurgical publication through review in the Philosophical Transactions. ${ }^{130}$ Pettus himself presented his motivation for writing: 'That I may divulge their [assayers'] chiefest and most curious Experiments and Practicks'. His effort was part of 'the free communication of such things as had many Ages before laid secret'. He further condemned those who, contrary to the spirt of epistemological openness, 'concealed under the Name of Philosophical Secrets'. ${ }^{131}$ It is intriguing too that Pettus, and Ercker, presented assaying as entangled with the broader sciences of 'chimistry' and 'alchimy' $[\mathrm{sic}] .{ }^{132}$ Alchemists and assayers shared interests in the 
purification, testing, and precise measurement of metals; practitioners of both employed precision balances. ${ }^{133}$ It was these shared instruments, recipes, and workshop techniques, and their experiential and experimental features, that proved mutually fascinating to eminent seventeenth-century gentlemen experimenters (including Robert Boyle and Isaac Newton) in their quest to uncover secrets of nature. ${ }^{134}$

While the activities of London's institutional assay workshops, and the tools, techniques and recipes of assay more generally, were of interest to metropolitan scholars, we should be very wary of pushing a model of practitioner/philosopher interaction too far. A warning shot was appositely fired by Pettus in Fleta minor. In the 'Metallick Dictionary' Pettus included an entry on Ercker; this artisan-author was said to be 'a renown'd Assay-Master', but also, ultimately, 'an humble minded industrious man'. This condescending representation of an institutional expert, whose works Pettus had himself dedicated many years to translating, is symptomatic of the broader seventeenth-century learned culture, in which 'artisanal bodily experience was absorbed into the work of the natural philosopher at the same time that the artisan himself was excised from it'. ${ }^{135}$ Gentlemen natural philosophers might appropriate assay knowledge cultures, whilst simultaneously denigrating the social status of practising artisans. Francis Bacon had set the tone when he praised the potential of 'experiments in the mechanical arts', while concurrently disparaging the artisan labouring ' with feeble effort and slight success'. ${ }^{136}$ Later in the seventeenth century, as the history of trades project was well underway, John Evelyn wrote to Robert Boyle of his unease in 'conversing with mechanical capricious persons'. ${ }^{137}$ This attitude on the part of gentlemen was evidently extended to the artisans employed within London's institutional assay workshops. Writing detailed descriptions of the complexity of assay, and the significance of trials for upholding the institutional reputation of the Tower mint, Isaac Newton as Master of the Mint also stressed - with no apparent irony that 'the Assaymaster acts only as a manual Artificer' and 'is only a manual Operator'. 'Refining \& assaying', Newton declared, 'are manual trades'. ${ }^{138}$

It would be inappropriate to give the final word here to condescending gentleman natural philosophers, engaged in the ongoing project of firming up the social boundaries of epistemological authority. This exploration of London's metallurgical practitioners, workshops, and manuscripts has uncovered a rich, complex culture of metropolitan expertise. Master assayers were highly skilled artisans who were expected to have extensive experiential knowledge, demanding technical competencies, extraordinary sensory responses, and agreeable personalities. This was a relatively intimate knowledge community, within which skills and institutional employment were largely, though not exclusively, passed down from father to son, or close male relative. London's institutional workshops of assay deserve a place in the seventeenth-century experimental urban topography, alongside instrument makers', apothecaries' and coffee shops, on which so much ink has been spilt. Embedded within corporate buildings and associated cultures of secrecy and commercial advantage, visibility and access to these workshops was, nonetheless, unlike any typical 
working or commercial site in early modern London. When London's practising assayers, or assaying dynasties, articulated and codified their embodied workshop experiences, they drew upon an established European tradition of metallurgical customs and techniques. These assay manuscripts were, however, unambiguously London-based. In presenting their expertise as a 'science', the assayers of the Goldsmiths' Company and the Royal Mint described rituals, social practices, and histories of knowledge making and witnessing that were unmistakably English and metropolitan.

${ }^{1}$ Goldsmiths' Hall Archive, London (GHA), Wardens accounts and court minutes (WA/CM), fo. 15v.

${ }^{2}$ The Pirotechnia of Vannoccio Biringuccio (tr. Cyril Stanley Smith and Martha Teach Gnudi), New York: The American Institute of Mining and Metallurgical Engineers, 1942, p. 136.

${ }^{3}$ Pamela O. Long, Openness, Secrecy, Authorship: Technical Arts and the Culture of Knowledge from Antiquity to the Renaissance, Baltimore: The Johns Hopkins University Press, 2001, Ch. 6.

${ }^{4}$ Lazarus Ercker; John Pettus, Fleta minor: The laws of art and nature, in knowing, judging, assaying, fining, refining and inlarging the bodies of confin'd metals (London, 1683), sig. A1v.

${ }^{5}$ Gerard de Malynes, Consuetudo, vel, Lex mercatoria; or, The ancient-law merchant, vol. 1 (London, 1622), p. 284.

${ }^{6}$ The diary of John Evelyn, Vol. 4. Kalendarium, 1673-1689, ed. by E. S. de Beer, Oxford: Clarendon Press, 1955, p. 138.

${ }^{7}$ BL Sloane MSS 1423, 2210.

${ }^{8}$ Ercker; Pettus, Fleta minor, sig. B2r-v.

${ }^{9}$ These institutional histories include: Thomas F. Reddaway and Lorna E. M. Walker, The Early History of the Goldsmiths' Company, 1327-1509, London: Edward Arnold, 1975; Christopher E. Challis, A New History of the Royal Mint, Cambridge: Cambridge University Press, 1991; John S. Forbes, Hallmark: A History of the London Assay Office, London: Unicorn, 1999.

${ }^{10}$ E. Zilsel, The Sociological Roots of Science, Dordrecht: Springer, 2000, p. 7-21; Paolo Rossi, Philosophy, Technology and the Arts in the Early Modern Era, New York: Harper \& Row, 1970; Pamela Smith and Paula Findlen, eds., Merchants and Marvels: Commerce, Science, and Art in Early Modern Europe, New York and London: Routledge, 2002; Pamela H. Smith, The Body of the Artisan: Art and Experience in the Scientific Revolution, Chicago: University of Chicago Press, 2006; Pamela Long, Artisan/Practitioners and the Rise of the New Sciences, 1400-1600, Corvallis OR: Oregon State University Press, 2011; Pamela H. Smith, Amy R. W.

Meyers, and Harold J. Cook, eds., Ways of Making and Knowing: The Material Culture of Empirical Knowledge, Ann Arbor: University of Michigan Press, 2014.

${ }^{11}$ Pamela O. Long, 'Power, patronage, and the authorship of Ars: from mechanical known-how to mechanical knowledge in the last scribal age', Isis, (1997) 88, pp. 1-41, at p. 4.

${ }^{12}$ Smith (2006), op. cit. (10).

${ }^{13}$ Deborah E. Harkness, The Jewel House: Elizabethan London and the Scientific Revolution, New Haven: Yale University Press, 2007, pp. 6, 10.

${ }^{14}$ Challis, op. cit. (9), p. 184.

${ }^{15}$ Christopher E. Challis, The Tudor Coinage, Manchester: Manchester University Press, 1978, pp. 1-3.

${ }^{16}$ Justine Bayley and Harriet White, 'Evidence for workshop practices at the Tudor mint in the Tower of London', in David Saunders, Marika Spring, and Andrew Meek, eds., The Renaissance Workshop, London: Archetype Publications, 2013, pp. 138-43.

${ }^{17}$ It is very likely that the varied workshop processes at the Mint, for example those of assaying, melting, and blanching, were undertaken in different 'houses' (or certainly, at least, separate chambers). See Challis, op. cit (15), pp. 14-16.

${ }^{18}$ The National Archives, Kew (TNA), T 48/92, fo. 22v.

${ }^{19}$ For a contemporary account of the Trial of the Pyx, see GHA, MS C II.2.1, fos. $28^{r}, 30^{r}$.

${ }^{20}$ The Goldsmiths' Company's assayer was variously known as the common assayer, assay master, and deputy assayer. These terms are used interchangeably in the company's archival records.

${ }^{21}$ Reddaway and Walker, op. cit. (9), pp. 164-65.

${ }^{22}$ GHA, MS 2524, fo. $13 v$.

${ }^{23}$ In the sixteenth century the customary weight of the sample taken for testing was either 15 or 30 grains. See Forbes, op. cit. (9), p. 21. 
${ }^{24}$ The de moneta of Nicolas Oresme and English Mint Documents (tr. Charles Johnson), London: Thomas Nelson and Sons, 1965, p. 81.

${ }^{25}$ In general: 'historical actors [...] in the course of controversy they attempt to deconstruct the taken-forgranted quality of their antagonists' preferred beliefs and practices, and they do this by trying to display the artefactual and conventional status of those beliefs and practices'. See Steven Shapin and Simon Schaffer, Leviathan and the Air-Pump: Hobbes, Boyle, and the Experimental Life, Princeton: Princeton University Press, 2011, p. 7.

${ }^{26}$ Georgius Agricola, De re metallica, (tr. by Herbert Hoover and Lou Hoover), New York, 1950, p. 223.

${ }^{27}$ For craft guilds and secrecy, see Long, op. cit. (3), pp. 3-4, 6-7, 13-14, 72-101; Karel Davids, 'Craft secrecy in Europe in the early modern period: a comparative view', Early Science and Medicine, (2005) 10, pp. 341-48.

${ }^{28} \mathrm{GHA}, \mathrm{MS} 2524$, fo. $55^{\mathrm{v}}$. This ordinance states that if any man 'reveals the secrets and good regulations of the craft to him, [a stranger] he shall be deprived of all the benefits of St Dunstan until in the presence of the whole livery he acknowledges his misdeeds or else he shall pay a fine of $40 \mathrm{~s}^{\prime}$.

${ }^{29}$ On civic parlours see: Paul Griffiths, 'Secrecy and authority in late sixteenth-and seventeenth-century London', The Historical Journal, (1997) 40, pp. 925- 51; Lena Cowen Orlin, Locating Privacy in Tudor London, Oxford: Oxford University Press, 2007, pp. 114, 146-51. For a discussion of 'secrecy as a dynamic social relation' see Koen Vermeir and Daniel Margocsy, 'States of secrecy: an introduction', BJHS, (2012) 45, pp. 153164.

${ }^{30}$ Walter Sherburne Prideaux, ed., Memorials of the Goldsmiths' Company (2 vols., London, 1896-7), I, p. 62.

${ }^{31}$ Forbes, op. cit. (9), p. 99. The term 'stranger' referred to foreign artisans.

${ }^{32}$ GHA, WA/CM, O2, fo. 194.

${ }^{33}$ Richard Rogers was employed as company assay master from 1559 to 1567.

${ }^{34}$ In 1566 Rogers was appointed assay master at the Tower mint.

${ }^{35} \mathrm{GHA}, \mathrm{WA} / \mathrm{CM}, \mathrm{K} 1$, fo. 316.

${ }^{36} \mathrm{GHA}, \mathrm{WA} / \mathrm{CM}, \mathrm{K} 1$, fos. 271, 321.

${ }^{37} \mathrm{GHA}, \mathrm{WA} / \mathrm{CM}, \mathrm{K} 1$, fos. $271,361,382$.

${ }^{38}$ John Reynolds was in post as company common assayer for a decade, from 1619 to 1629.

${ }^{39} \mathrm{GHA}, \mathrm{WA} / \mathrm{CM}, \mathrm{Q} 1$, fos. $112 \mathrm{r}-\mathrm{v}$.

${ }^{40} \mathrm{GHA}, \mathrm{WA} / \mathrm{CM}, \mathrm{Q1}$, fo. $113 \mathrm{r}$.

${ }^{41}$ Prideaux, op. cit. (30), vol. I., p. 152.

${ }^{42} \mathrm{GHA}, \mathrm{WA} / \mathrm{CM}, \mathrm{Q1}$, fo. $122 \mathrm{v}$.

${ }^{43}$ Prideaux, op. cit. (30), vol. I., p. 139.

${ }^{44}$ Challis, op. cit. (9), p. 407.

${ }^{45}$ TNA, Mint 19/l, fo. 90r.

${ }^{46}$ TNA, Mint 19/I, fo. $98 \mathrm{v}$.

${ }^{47}$ Bert De Munck and Hugo Soly, 'Learning on the shop floor' in historical perspective', in Bert De Munck, Steven L. Kaplan and Hugo Soly (eds.), Learning on the Shop Floor: Historical Perspectives on Apprenticeship, New York, Oxford: Berghahn Books, 2007, pp. 3-32, at p. 7; Patrick Wallis, 'Apprenticeship and training in premodern England', Journal of Economic History (2008) 68, pp. 832-861, pp. 847-48.

${ }^{48}$ After institutional anxieties about a 'proper [skilled] succession' of assayers at the Mint, there was an especial drive from the mid-eighteenth century to ensure that 'the Mint always had a trained assayer waiting in the wings'. See Challis, op. cit. (9), pp. 407-9.

${ }^{49}$ Prideaux, op. cit. (30), vol. II., pp. 33, 73, 140.

${ }^{50}$ William Eamon, 'Arcana disclosed: the advent of printing, the books of secrets tradition and the development of science in the sixteenth century', History of Science, (1984) 22, pp. 111-150.

${ }^{51}$ Elaine Leong and Alisha Rankin, 'Introduction: secrets and knowledge' in Leong and Rankin (eds.), Secrets and Knowledge in Medicine and Science, 1500-1800, Farnham, Burlington, VT.: Ashgate, 2011, pp. 1-20, at p. 6. ${ }^{52}$ Pamela Smith, "What is a secret? Secrets and craft knowledge in early modern Europe', in Leong and Rankin, op. cit. (51), pp. 47-66, at p. 49.

${ }^{53} \mathrm{GHA}, \mathrm{WA} / \mathrm{CM}, \mathrm{O3}$, fo. 454.

${ }^{54} \mathrm{GHA}$, MS C II.2.1.

${ }^{55}$ William Eamon, Science and the Secrets of Nature: Books of Secrets in Medieval and Early Modern Culture, Princeton: Princeton University Press, 1994, pp. 112-20.

${ }^{56}$ There are two manuscript versions of The Gouldesmythes' Storehowse, and five known copies. The copy owned by the Goldsmiths' Company is the longer version and contains a discussion of the specialisation of the trade. See Janelle Jenstad, “The Gouldesmythes Storehowse' early evidence for specialisation', The Silver Society Journal, (1998) 43, pp. 40-43, at p. 40. 
${ }^{57}$ Anne Duffin, 'Gamon, Hannibal (bap. 1582, d. 1650/51), Church of England clergyman', Oxford Dictionary of National Biography, Oxford: Oxford University Press, 2018

<http://www.oxforddnb.com/view/10.1093/ref:odnb/9780198614128.001.0001/odnb-9780198614128-e10329> [accessed 25 June 2018].

${ }^{58} \mathrm{GHA}$, WA/CM, O2, fo. 313; O3, fo. 454.

${ }^{59} \mathrm{GHA}, \mathrm{WA} / \mathrm{CM}, \mathrm{O} 3$, fo. 454.

${ }^{60}$ See Records of London's Livery Companies Online: Apprentices and Freemen 1400-1900 (ROLLCO)

<http://www.londonroll.org > [accessed 20 October 2012].

${ }^{61}$ See for example GHA, MS C II.2.1, fos. $23^{r-v}, 33^{v}$.

${ }^{62}$ BL Harley MS 38.

${ }^{63}$ Challis, op. cit. (15), pp. 37-8; Steven Gunn, Henry VII's New Men and the Making of Tudor England, Oxford:

Oxford University Press, p. 74.

${ }^{64} \mathrm{GHA}$, MS C II.2.1, fos. $28^{r}, 30^{\mathrm{r}}$.

${ }^{65}$ Long, op. cit. (3), p. 246.

${ }^{66}$ Pamela Long, 'The openness of knowledge: an ideal and its context in sixteenth-century writings on mining and metallurgy', Technology and Culture, (1991) 32, pp. 318-55, at pp. 334-35, 355.

${ }^{67}$ TNA, T 48/92.

${ }^{68}$ Public trust in the purity of the coinage was essential for the success of the Financial Revolution, see Carl Wennerlind, Casualties of Credit: The English Financial Revolution, Cambridge, Mass., London: Harvard University Press, 2011, Chs 3 and 4.

${ }^{69}$ BL Harley MS 660. Mint and Moneta has numerous illustrations of tools and equipment found in the assayer's workshop which are not included in this earlier manuscript on coin and assaying.

70 TNA, T 48/92, fo. $5 \mathrm{v}$.

${ }^{71}$ Steven Shapin, 'The house of experiment in seventeenth-century England', Isis (1988) 79, pp. 373-404.

72 GHA, MS C II.2.1, fo. $4^{\mathrm{v}}$.

${ }^{73}$ The pirotechnia of Vannoccio Biringuccio, p. 48.

${ }^{74}$ Long, op, cit. (66), p. 350; Lazarus Ercker, Treatise on Ores and Assaying (tr. Anneliese Grünhaldt Sisco and Cyril Stanley Smith), Chicago: University of Chicago Press, 1951, p. 194.

${ }^{75}$ GHA, MS C II.2.1, fo. $5^{\vee}$.

${ }^{76}$ Practitioners of the new experimental science expressed concerns about the deceptive possibilities of ordinary (and unaided) sense perception. See Eamon, op. cit. (55), pp. 292-94, Smith, op. cit. (10), pp. 193, 222-23, 228.

${ }^{77}$ For a further discussion of the sensory knowledge of artisans, see Pamela Smith, 'Vermillion, mercury, blood, and lizards: matter and meaning in metalwork', in Ursula Klein and E. C. Spary (eds), Materials and Expertise in Early Modern Europe: Between Market and Laboratory, Chicago: University of Chicago Press, 2010, pp. 29-49, at pp. 32-33.

78 Georgius Agricola, De re metallica, p. 243.

${ }^{79}$ The pirotechnia of Vannoccio Biringuccio, p. 211.

${ }^{80} \mathrm{GHA}$, MS C II.2.1, fo. $76^{\mathrm{v}}$.

81 TNA, T 48/92, fos. 11r, $16 \mathrm{v}$.

${ }^{82}$ GHA, MS C II.2.1, fo. 6 r. Tellingly he specifically uses sensory language to talk about tool technology.

${ }^{83}$ The pirotechnia of Vannoccio Biringuccio, p. 281.

${ }^{84}$ Ercker; Pettus, Fleta minor, p. 93.

${ }^{85}$ Allison Stielau, 'The weight of plate in early modern inventories and secularization lists', Journal of Art Historiography, (2014), 11.

${ }^{86}$ The pirotechnia of Vannoccio Biringuccio, p. 360.

${ }^{87}$ TNA, T 48/92, $4 \mathrm{v}$.

${ }^{88}$ TNA, T 48/92, 12v-13r.

${ }^{89}$ Georgius Agricola, De re metallica, XXX. See also Marcus Popplow, 'Why draw pictures of machines? The social contexts of early modern machine drawings', in Wolfgang Lefevre (ed.), Picturing Machines 1400-1700, Cambridge, Massachusetts; London: MIT Press, 2004, pp. 17-48, at p. 26.

${ }^{90}$ Shapin and Schaffer, op. cit. (25), Ch. 2; Smith and Schmidt, 'Introduction: knowledge and Its making in early modern Europe', in eadem., Making Knowledge in Early Modern Europe: Practices, Objects, and Texts, 14001800, Chicago; London, 2007, pp. 1-16, at p. 13.

${ }^{91}$ Patrick Wallis and Catherine Wright, 'Evidence, artisan experience, and authority in early modern England', in Smith, Meyers, and Cook, op. cit. (10), pp. 138-163.

${ }^{92} \mathrm{GHA}$, MS C II.2.1, fos. $27^{r-v}$. 
${ }^{93} \mathrm{GHA}$, MS C II.2.1, fo. $27^{v}$. The goldsmiths are undertaking a material trial, and their honour and expertise are on trial. See Simon Wortham, 'Sovereign counterfeits: the trial of the pyx', Renaissance Quarterly, (1996) 49, pp. 334-59, at p. 336.

${ }^{94} \mathrm{GHA}, \mathrm{MS}$ C II.2.1, fo. $28^{\mathrm{v}}$.

95 TNA, T 48/92, fos. 22v-23r.

96 TNA, Mint 19/I, fo. 90r.

${ }^{97}$ Eamon, op. cit. (55), pp. 4-5.

${ }^{98}$ Stephen Johnston, 'Mathematical practitioners and instruments in Elizabethan England', Annals of Science, (1991) 48, pp. 319-344, at pp. 326-27; William Eamon, 'How to read a book of secrets', in Leong and Rankin, op. cit. (51), pp. 23-46, at p. 30. See also Paola Bertucci, Artisanal Enlightenment: Science and the Mechanical Arts in Old Regime France, New Haven: Yale University Press, 2017, Ch. 5, esp. pp. 147, 153-55.

${ }^{99}$ Long, op. cit. (3), p. 188.

${ }^{100}$ Bradin Cormack and Carla Mazzio have suggested that a 'how-to' book 'was useful in two ways, instructing individual practitioners and consolidating the claims of the group as a whole to a field of knowledge or expertise'. See Book Use, Book Theory: 1500-1700, Chicago: University of Chicago Press, 2005, p. 85. See also Natasha Glaisyer and Sara Pennell, Didactic Literature in England 1500-1800: Expertise Constructed, Aldershot: Ashgate, 2003, p. 9.

${ }^{101}$ GHA, MS C II.2.1, fos. 5v , 74v, $76^{r}$.

102 Long, op. cit. (3), p. 177.

${ }^{103} \mathrm{GHA}, \mathrm{MS}$ C II.2.1, fo. $32^{\mathrm{r}}$

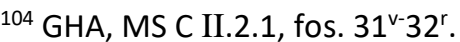

105 Ercker; Pettus, Fleta minor, p. 228.

106 Natalie Zemon Smith, 'Beyond the market: books as gifts in sixteenth-century France', Transactions of the Royal Historical Society, (1983) 33, pp. 69-88, at p. 72.

107 The pirotechnia of Vannoccio Biringuccio, p. 363.

108 Ibid., p. 364.

${ }^{109} \mathrm{GHA}$, WA/CM, O3, fos. 551-52.

${ }^{110}$ Forbes, Hallmark, pp. 70-71.

${ }^{111}$ GHA, WA/CM, Q1, fo. 21r.

112 David Mitchell, Silversmiths in Elizabethan and Stuart London: Their Lives and their Marks, Woodbridge: The Boydell Press, 2017, pp. 77-79.

113 GHA, MS C II.2.1, 32r.

114 'Blanching' referred to the process of whitening coins. 'Shearing' involved cutting and clipping.

115 Challis, op. cit. (9), p. 267.

116 BL Harley MS 38, fo. 237r.

117 The pirotechnia of Vannoccio Biringuccio, p. 358.

${ }^{118}$ Robert Latham and William Matthews (eds), The Diary of Samuel Pepys, vol. 4 (1971): 1663, p. 143.

${ }^{119}$ C. S. Knighton, 'Pepys, Samuel (1633-1703), naval official and diarist', Oxford Dictionary of National Biography, Oxford: Oxford University Press, 2018

<http://www.oxforddnb.com/view/10.1093/ref:odnb/9780198614128.001.0001/odnb-9780198614128-e21906> [accessed 25 June 2018].

120 The Diary of Samuel Pepys, pp. 143, 145. 'Experiment' had an ambiguous meaning at this date, signalling: 'The action of trying anything, or putting it to proof; a test, trial'. "experiment, n.". OED Online, Oxford: Oxford University Press, 2019 <http://www.oed.com.chain.kent.ac.uk/view/Entry/66530> (accessed January 31, 2019).

${ }^{121}$ Eamon, op. cit. (55); Long, op. cit. (3).

122 Francis Bacon, New Atlantis, in Susan Bruce (ed.), Three Early Modern Utopias (Oxford, 1999), pp. 151-86, at pp. $180-83$.

${ }^{123}$ Harkness, op. cit. (13), p. 213.

${ }^{124}$ Pamela Smith, 'Laboratories', in Katherine Park ed., The Cambridge History of Science. Volume 3, Early Modern Science, Cambridge: Cambridge University Press, 2006, pp. 290-305, at p. 296; Rob Iliffe, 'Material doubts: Hooke, artisan culture and the exchange of information in 1670s London', BJHS (1995) 28, pp. 285318; Jim Bennett, 'Shopping for instruments in Paris and London', in Smith and Findlen, op. cit. (10), pp. 370395.

${ }^{125}$ Eamon, op. cit. (55), pp. 342-45; Kathleen H. Ochs, 'The Royal Society of London's history of trades programme: an early episode in applied science', Notes and Records (1985) 39, pp. 129-158, at pp. $130-31$. 
126 "assay, n.". OED Online. Oxford: Oxford University Press, 2018

$<$ http://www.oed.com.chain.kent.ac.uk/view/Entry/11756?rskey=jtrlNj\&result=1> (accessed June 25, 2018).

${ }^{127}$ This connection or parallel - between the reporting of assay trials and the recording of experimental

practice - has also been made in Cesare Pastorino, 'The mine and the furnace: Francis Bacon, Thomas Russell, and early Stuart mining culture', Early Science and Medicine, (2009) 14, pp. 630-60, at pp. 654-55.

${ }^{128}$ Shapin and Schaffer, op. cit. (25), Ch. 2; Eamon, op. cit. (55), p. 289.

${ }^{129}$ Fleta minor was reprinted in 1686 and 1689.

${ }_{130}$ Phil. Trans. 13: 147 (1683), pp. 189-96. It was noted that Pettus 'asserts his own experience'.

${ }^{131}$ Ercker; Pettus, Fleta minor, B2r-v.

132 "The words "alchemy" and "chemistry" were used interchangeably to refer to the same body of activities throughout most of the seventeenth century, and only during the eighteenth century were distinctions similar to those in common modern usage rigidly drawn between the two'. See Lawrence M. Principe and William R. Newman, 'Some problems with the historiography of alchemy', in William R. Newman and Anthony Grafton, (eds.), Secrets of Nature: Astrology and Alchemy in Early Modern Europe, Cambridge, Mass., London: MIT Press, 2001, pp. 385-431, at p. 386.

${ }^{133}$ William R. Newman and Lawrence M. Principe, Alchemy Tried in the Fire: Starkey, Boyle, and the Fate of Helmontian Chymistry, Chicago and London: University of Chicago Press, 2002, pp. 38-39, 41, 46, 49. See also William R. Newman, 'Alchemy, assaying, and experiment', in Frederic L. Holmes and Trevor H. Levere (eds.), Instruments and Experimentation in the History of Chemistry, Cambridge, Mass, and London: MIT Press, 2000, pp. 35-54.

${ }^{134}$ Tara E. Nummedal, 'Words and works in the history of alchemy', Isis (2011) 102, pp. 330-337, at p. 331.

${ }^{135}$ Smith (2006), op. cit. (10), p. 186.

${ }^{136}$ Francis Bacon, Novum Organum: With Other Parts of the Great Instauration (tr. and ed. Peter Urbach and John Gibson), Chicago: Open Court, 1994, pp. 26, 44.

${ }^{137}$ Letter from Evelyn to Boyle, 9 July 1659, quoted in Walter E. Houghton, 'The history of trades: its relation to seventeenth century thought', Journal of the History of Ideas (1941) 2, pp. 33-60, at p. 48.

138 TNA, Mint 19/I, fos., 90r, 91r, 99r.

Notably Robert Boyle referred to his workshop technicians (or 'invisible actors') as 'operators'. See Shapin, op. cit. (71), p. 395. 